\title{
The Design of Intervention among Survivors of Disaster
}

\author{
Siti Urbayatun ${ }^{1}$, Erlina Listyanti Widuri ${ }^{1}$, Ani Muttaqiyatun ${ }^{2}$, Dewi Eskawati ${ }^{1}$ \\ ${ }^{1}$ Faculty of Psychology, Universitas Ahmad Dahlan, Yogyakarta, Indonesia \\ ${ }^{2}$ Faculty of Economic, Universitas Ahmad Dahlan, Yogyakarta, Indonesia
}

\begin{tabular}{l}
\hline \hline Article Info \\
\hline Article history: \\
Received Jun 12, 2014 \\
Revised Aug 20, 2014 \\
Accepted Aug 26, 2014
\end{tabular}

Keyword:

Disaster

Intervention

Self-confidence

Survivor

\begin{abstract}
Indonesia is a region that is frequently hit by disasters, especially the earthquake because of geological factors. Earthquake in 2006 in the region of Yogyakarta and Central Java still has problems to this day, the basics of the economy has not fully recovered, disabled people coud not work as usual, people experience a variety of stressors such as income and material stress and emotional stress. The aimed of this study was to find out the effect of cognitive and religious intervention to cope with stress of disaster. The subjects of this study were people in Bantul who exposed to stress due to disasters such as disability and individuals who have low self-confidence because of disabilty. The method of the study was a responsive action research. Data were collected through observation, interviews, focus group discussions, psychoeducation and training. The study found that cognitive and religious intervention has positive impact on recovery of the subject, for example increase on self-confidence of individual and decrease in the mean of SUD (subjective unit disturbances) score of familie's subject member. The interventions were usefull to improve the future intervention of disabled persons and people who experience stress of family member's disability.
\end{abstract}

Copyright (C) 2014 Institute of Advanced Engineering and Science. All rights reserved.

\section{Corresponding Author:}

Ani Muttaqiyatun, Departement of Economic, Ahmad Dahlan University, Jalan Kapas No 9, Semaki, Yogyakarta, Indonesia.

Email: animtq@gmail.com

\section{INTRODUCTION}

Disability harrastment has long been reported in the literature. Holzbauer \& Conrad (2010) identified six major type of disability harrastment that can be placed on continuum from least assertive to most aggressive [1]. The less assertive types are pigeonhole, abandon and manipulate and the most agrresive types are belittle, scare and violate. Lauster (2012) stated that physical disability can lead to inferiority [2]. Oermarjoedi (2003) stated that cognitive conflicts can lead to cognitive distortions and cause low self confidence. The suitable intervention has not been found for people suffering disability [3].

According Wiranegara (2010) self confidence is a person who can control the character and lifeplans or someone who knows him and his ability to use his ability to do something [4]. The basic principle of cognitive approach emphasizes the capacity ofthe individual inself-discovery and change their ways of thinking in order to obtain a different view of self and surroundings. Individuals are taught to identify aberrant patterns of thought and disrupted through the evaluation process, by identifying, observing and monitoring automatic thoughts. Individuals learn to distinguish between personal thoughts and events in the real world as well as learn how the mind can affect feelings and behavior even external events.

Religious coping which is one of the representation religious teachings should be developed as a nindigenous wealth owned communities to deal with disasters. Based on previous study amongs survivors of the earthquake in the religious area in Jejeran, Bantul, pray and acts of worship can improve post traumatic 
growth [5]. This is in line with previous studies that earthquake survivors suffering physical disability used religious coping such as "sholatul lail" or pray night [6]. Coping derived from the basic of Islam, such as keep close relationship to God could promote recovery [6],[7]. Amawidyati \& Utami (2007) found that religiosity in creases psychological well-being to the earthquake survivors [8]. Another study enriches previous findings that there is positive correlation between positive religious coping styles and selfacceptanceon earthquake survivors [9].

This study examined the effectiveness of some programs in helping people cope with the crisis caused by the disaster. Some programs such as training and psychoeducation on victim earthquake suffering disabilities and their families need to be empowered in the process of intervention and assistance for vulnerable groups in the community.

\section{RESEARCH METHOD}

The subject of this research was eartquake survivors suffering physical and their family in the area of Sewon Bantul. Samples were selected based on screening of 30 subjects and has been selected 16 subjects with low to moderate of self confidence.

Scale used in the research was the confidence scale that the reliability coefficient alpha $(\alpha)=0.943$ with different power index item (rit) 0.262 lowest and highest 0.771 so it can be said that the item is quite valid and reliable.

The cognitive training modules have conducted professional judgment of practitioners and academics in the field of psychology and the simulation module by psychologists. The training method was experiential learning, lectures, discussions and assignments. The training conducted six sessions. Each session is conducted for 75 minutes up to 120 minutes.

\section{RESULTS AND ANALYSIS}

\subsection{The results of Descriptive analysis}

The intervention used combination of cognitive approach and Islamic approach. The quantitative approach has done for testing the differences between the experimental group self confidence and control group after cognitive training and islamic training and the qualitative approach is used to determine the dynamics that occurred during the process of intervention.

Tabel 1. The score of self-esteem of survivors suffering physical disability before selection

\begin{tabular}{llllc}
\hline \multicolumn{1}{c}{ Standard } & \multicolumn{1}{c}{ Norm } & category & $\mathrm{N}$ & $\%$ \\
\hline $\mathrm{x}<\mu-1 \sigma$ & $\mathrm{x}<56$ & Rendah & 0 & 0 \\
$\mu-1 \sigma \leq \mathrm{x}<\mu+1 \sigma$ & $56 \leq \mathrm{x}<84$ & Sedang & 16 & 53.33 \\
$\mu+1 \sigma \leq \mathrm{x}$ & $84 \leq \mathrm{x}$ & Tinggi & 14 & 46.67 \\
Sum $=$ & & & 30 & 100 \\
\hline
\end{tabular}

Through the categorization of the self confidence scale scores, there searcher selects subjects whom met the criteria, but after being asked the subject's willingness to participate only 14 subjects were willing to be the subject of research. Subject of a number of 14 people were selected by random to be grouped in the experimental group and the control group. Each group consists of 7 (seven) people. The subjects of the experimentare given training where as control subjects is a waiting list and will be given training by the end of the session.

\subsection{The results of Friedman Test, Wilcoxon Test and Mann Whitney U-Test}

Friedman's analysis of the test results prove that the hypothesisis accepted, ie, there is a difference in self confidence between the pre-test, post-test and follow-up on the subject of the experimental group (chisquare $=12.074 ; \mathrm{p}=0.002 ; \mathrm{p}<0.01$ )

Wilcoxon analysis of the test results prove that there is a difference in self confidence between the pre-test and post-test on the subject of the experimental group $(Z=-2.366 ; p=0.018 ; p<0.05)$; there is a no difference in self confidence between the post-test and follow-up on the subject of the experimental group $(Z=-0.949 ; p=0.343 ; p>0.05)$; there is adifference in self confidence between the pre-test and follow-up on the subject of the experimental group $(Z=-2.371 ; p=0.018 ; p<0.05)$. 
Mann-Whitney U-test showed that there are differences in the level of self confidence between the experimental group and the control group (pre-post: $Z=-3.151 ; p=0.02 ; p<0.01$ ) in which the average increased of experimental group level is 11, while the control group is 4 .

Mann-Whitney U-test showed that there are differences in the level of self confidence between the experimental group and the control group (post-follow up: $Z=-2.067 ; p=0.039 ; p<0.05$ ) in which the average increased of experimental group level is 9,79, while the control group is 5,21.

Mann-Whitney U-test showed that there are differences in the level of self confidence between the experimental group and the control group (pre-follow up: $Z=-3.137 ; p=0.002 ; p<0.01$ ) in which the average increased of experimental group level is 11, while the control group 4.

This study is in line with Aliah's study (2008) which found the presence of a significant positive relationship between positive thinking with self confidence [10]. There was the higher the positive thinking, the higher the confidence. Participants may change the negative and pessimistic thoughts into positive thoughts that appear to be more optimistic. Seligman $(1991 ; 2005)$ states that pessimism due to the negative beliefs against him were based on a wrong way of thinking; by changing the way of thinking of negative into a positive, the individual who originally had a pessimistic attitude would be more optimistic [11],[12]. The results ofthis study alsosupport thestudyof meta-analysis byHarriset al. (2009) and Pratiand Pietrantoni (2009) that found a strong relationship between religious coping and post-traumatic growth [13],[14]. Ting and Watson (2007) found that the feeling that God is present in his suffering can lead to individual growth and experiencing transformation [15].

Based on the categorization of confidence before the training $100 \%$ subject are still on moderate self confidence categorie and after training $71.43 \%$ of subject become high on self confidence and after followup $100 \%$ of subject on the category of high self esteem.

The results showed that there is improvement of self confidence amongs physical disability survivors. Subjects who consistently have increased scores confidence from the pre-test, post-test and followup is subject SG, IT, JR, SY, MY and BS. While IK is still not consistent on self confidence's score.

\subsection{Analysis of SUD decline before and after training}

The study also conducted an analysis of the effects of a given religious training in all subjects before and after training. There were 2 subjects drop out from training, soonly 12 subjects participate on the Islamic training. There is decrese of mean of SUD (subjective units of disturbances) of subject from 2.9 to 1.8 , so there is differences of before and after training by 1.1 point.

\subsection{The analysis of Focused-Group Discussion}

After the FGD with the chairman of the DPO (Difable Persons Organizations), turns out the problems still perceived by people with physical disabilities and their families. There were subject who feel stress because of economic factors and psychological factors such as subject of DPO members "Satu hati" and "Lindhu Asih" and there was a child that still traumatized. People with paraplegia need guidance on home-care treatment of decubitus. There were subjects of paraplegia still not join the activities in the community so the next intervention could give them training of life skills and psycho-social assistance.

\section{CONCLUSION}

Based on result of the study, it can be concluded that cognitive and Islamic approach wass usefull to improve self- confidence and decrease disturbance of the subject suffering physical disability. Although after the FGD it seen that some subjects were still stressed and need physiological and psychosocial support.

\section{ACKNOWLEDGEMENTS}

This research can not be done without the help of various parties, especially pronounced appreciation and thanks to Kopertis V DIY, Ministry of Educationand Culture, DIPA Number: $1142.13 / \mathrm{K} 5 / \mathrm{KL} / 2013$.

\section{REFERENCES}

[1] Holzbauer, J.J. \& Conrad, C.F., “A typology of disability harrastment in secondary schools”, Career Development for Exceptional Individuals, DOI. 10.1177/0885728810378681, October 2010.

[2] Lauster, Peter, “Tes Kepribadian”. Penerjemah: D.H. Gulo. Jakarta: Bumi Aksara, 2012. 
[3] Oemarjoedi, A. Kasandra, "Pendekatan Cognitive Behavior dalam Psikoterapi", Jakarta: Kreativ Media, 2003.

[4] Wiranegara, Chibita, "Dahsyatnya Percaya Diri: Total Self-Confidence", Yogyakarta: New Diglossia, 2010.

[5] Urbayatun, S., "Hubungan antara koping religius sufistik dengan pertumbuhan pasca trauma pada Ibu-ibu di Jejeran, Bantul", Laporan Penelitian, Universitas Ahmad Dahlan Yogyakarta, $2010 \mathrm{~b}$.

[6] Urbayatun, S., "Studi kualitatif tentang dampak positif gempa bumi bagipenyintas gempa yang mengalami cacat fisik". Laporan Penelitian, Universitas Ahmad Dahlan Yogyakarta, 2010a.

[7] Kumara, A. \& Susetyo, Y. F., "Hubungan sistem kepercayaan dan strategi menyelesaikan masalah pada korban".

[8] Amawidyati, S.A.G. \& Utami, M. S., "Religiusitas dan psychological well-being pada korban gemp", Jurnal Psikologi, vol/issue: 34(2), pp. 164-176, 2007.

[9] Trimulyaningsih, N. \& Rachmahana, R. S., "Postive religious coping style dan penerimaan diri pada survivor gempa Yogyakarta”, Jurnal Psikologi UIN Sunan Kalijaga, vol/issue: I(1), pp. 74-102, 2008.

[10] Aliah, Nur, "Hubungan Berfikir Positif dan Kepercayaan Diri pada Atlet PencakSilat dalam Menghadapi Pertandingan”, Naskah Publikasi, Yogyakarta: Universitas Islam Indonesia, 2008.

[11] Seligman, M. E. P., ”Learned Optimism”, New York, Alfred A. Knof Publishers, 1995.

[12] Seligman, M. E.P., “Authentic Happiness: Menciptakan Kebahagiaandengan Psikologi Positif”, Penerjemah: E.Y. Nukman. Bandung: Mizan, 2005.

[13] Harris, J.I., Erbes, C.R., Engdahl, B.E., Olson, R.H., Winskowski, A.M. \&McMahill, J, "Christians religious bencana gempa bumi”, Jurnal Psikologi, vol/issue: 35(2), pp. 116-150, 2008.

[14] Prati, G. \& Pietrantoni, L., "Optimisme, social support and coping strategiesas factors contributing to posttraumatic growth: A meta-analysis", Journal of Loss and Trauma, vol. 14, pp. 364-388. DOI: 10.1080/15325020902724271, 2009.

[15] Ting, R. Sing-Kiat \& Watson, T., "Is suffering good? an explorative study on the religious persecution among chinese pastors", Journal of Psychologyand Theology, vol/issue: 35(3), 202-213, 2007, retreived 7 April 2008 from www.questia.com. 